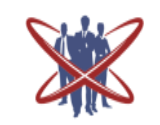

Open access Journa

International Journal of Emerging Trends in Science and Technology

DOI: https://dx.doi.org/10.18535/ijetst/v7i1.01

\title{
Success Rate of Endo Crowns- Reported by Dental Practitioners in Riyadh City, Saudi Arabia
}

Authors

\author{
Abdulrahman Habash ${ }^{1}$, Firas Basoudan ${ }^{1}$, Hassan Alwayil ${ }^{1}$, \\ Othman Alrashed $^{1}$, Basam Alarfaj ${ }^{1}$, Shahzeb Ansari ${ }^{2}$ \\ ${ }^{1}$ Dental Interns, Riyadh Elm University, Riyadh, Saudi Arabia \\ ${ }^{2}$ Lecturer Preventive Dentistry, Riyadh Elm University, Riyadh, Saudi Arabia
}

\begin{abstract}
Aim of study: To investigate the successful rate for Endo crowns done by Saudi doctors.

Materials and Methods: survey study contain explanatory questions about the problems of Endo crowns may doctor face it, collected from sample size 100 of Dental Senior, Intern and specialties, the data was subjected to statistical analysis using SPSS version 19.

Descriptive as well as inferential statistics were done including frequencies, mean and Chi square test with the value of significance kept under 0.05 .

Results: our result showed that there is statistically significant increase of successful rate of endo crowns depends on the survey questions.

Conclusions: Within the limits of this study it can show the efficiency of Endo crowns.
\end{abstract}

\section{Introduction}

The Endodontic Crowns considered one of many choices to cover a tooth after root canal treatment that lost huge amount of tooth structure. These teeth will lose their strength after removing the pulp and surrounding dentine. So after that it may need intra radicular post with or without core to strengthen the restoration.

To prevent destroying more of the sound tooth structure the endo crown considered alternative restoration. It combined the intra radicular post, core, and crown in mono block restoration. It set and fill the internal part of the pulp chamber and cavity margin depend on that it can achieve both macro and micro-mechanical.

One of the advantages of this type of restorations that is the preparation remove less amount of sound tooth structure and reduce the chair time for the patient.

\section{Objective of the Study}

The objective of the present study is to evaluate the problems that can affect the efficiency and inference of successful rate of Endo crowns.

\section{Materials and Methods}

This is a survey study.

Study subject: Dental senior, interns and doctors of Riyadh Elm University, King Saud University, Segal Private clinics and Al Habib Clinics. The target sample size was 100 male and female Doctors and students.

The survey contained questions about: Gender, Academic degree, number of failed cases, reasons, fracture resistant compared to Full coverage crowns, bonding and cost.

\section{Methods}

A closed ended questionnaire constructed, sent through Website links and printed papers used Survs survey. The data subjected to statistical analysis used SPSS version 19. Descriptive as well as inferential statistics were done including frequencies, mean and Chi square test with the value of significance kept under 0.05 . 


\section{Results}

This study involved $\mathrm{N}=100$ dental practitioners, which included $60 \%$ males and $40 \%$ females (figure 1). As far as the academic degree distribution was concerned, $35 \%$ were dental interns, $24 \%$ were dental seniors and $41 \%$ prosthodontists (figure 2).

Table 1 shows the comparisons of survey responses on the basis of gender. It can be noted from the findings that there was no significant difference between males and females when inquired about the number of patients treated by placing endo-crown (p-value: 0.621).

Similar findings were reported when inquired about the main problem of endo-crowns being secondary caries (p-value: 0.972), endo-crowns causing vertical root fracture ( $\mathrm{p}-$ value: 0.415 ), endo-crowns having long life span ( $\mathrm{p}$-value: 0.134 ), endo-crowns allowing longer life span for RCT (p-value: 0.199), endo-crowns costing less than all ceramic crowns (p-value: 0.078) and minimal preparation effecting the bonding ( $\mathrm{p}$ value: 0.426 ).

Slightly different results were observed when compared the findings on the basis of academic degree (table 2). There were significant comparisons observed when inquired the participants about endo-crowns having long life span than all ceramic crowns (p-value: 0.044). $17 \%$ of the dental seniors strongly disagreed as compared to $0 \%$ dental interns and $2 \%$ prosthodontists. Additionally, another statistically significant difference was observed when inquired about the endo-crowns being less costly than all ceramic crowns (p-value: 0.012). It can be noted from the table that $89 \%$ of dental interns disagreed as compared to $66 \%$ dental seniors and $90 \%$ prosthodontists.

The success rates of endo endo crowns is $99 \%$ with follow up period for 6 to 18 months. The mean number of teeth is 345 posterior and anterior were included in the assessment done by 41 Prosthodontic Doctors, 24 Dental seniors and 35 Dental interns from (Riyadh Elm University, King Saud University, "Sigal Private clinics" and "Al
Habib Clinics" and many of Dental clinics in Riyadh). (figure 3).

Failure due to debonding of the endo crowns occurred mostly in the $3^{\text {rd }}$ molar for two cases and due to secondary caries for two cases.

The analysis of endo crowns fracture strength in anterior and posterior teeth proved considerable differences from conventional methods including intra radicular posts with direct composite resin.

Endo crowns provide its preferences than all coverage crowns because of the less destruction of sound tooth structure.

The Cost of endo crowns mostly equal to full coverage crown.

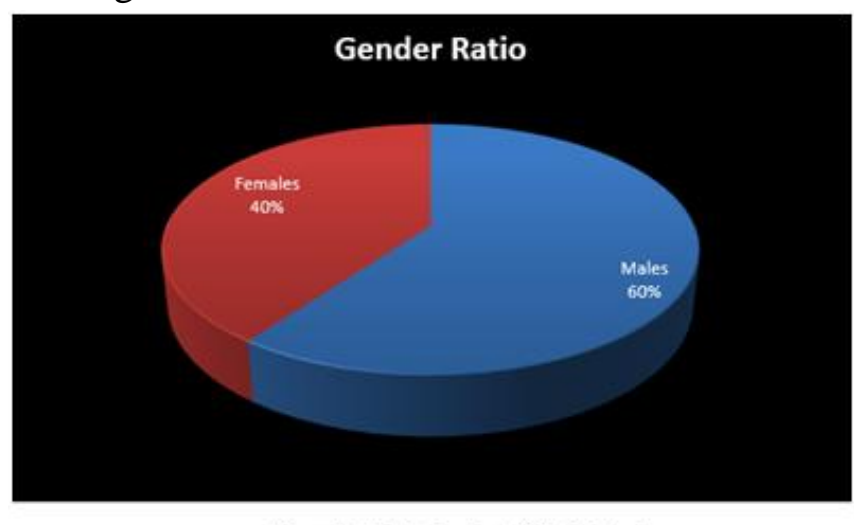

Figure 1: Male to female ratio in this study

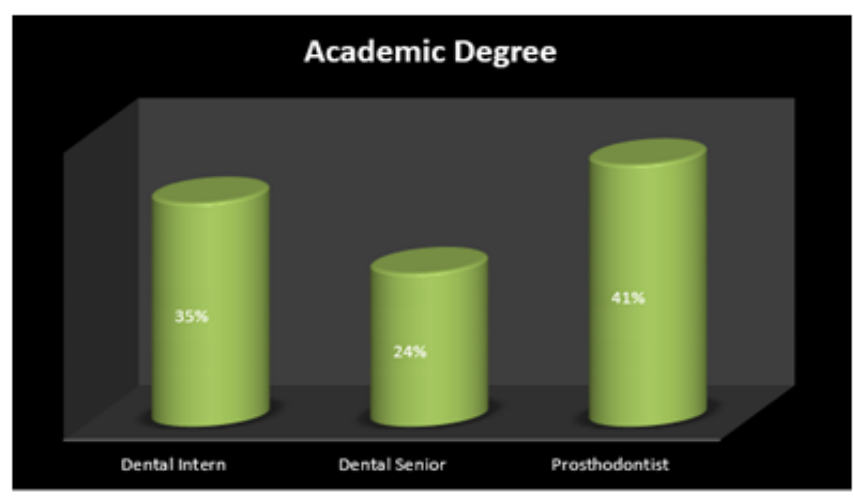

Figure 2: Academic degree of study participants

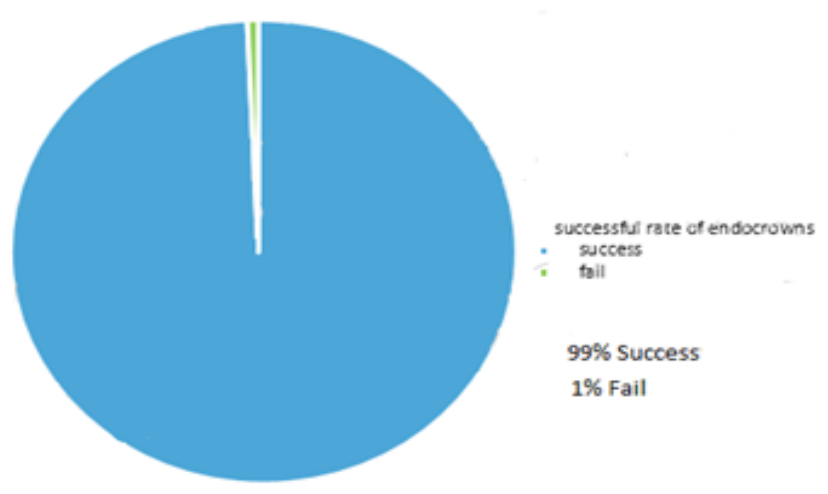

Figure 3: Success rate of Endocrowns 


\begin{tabular}{|c|c|c|c|}
\hline Survey Questions & Males & Females & P-value \\
\hline $\begin{array}{l}\text { How many patients did you } \\
\text { treat by placing Endocrown in } \\
\text { your clinic? }\end{array}$ & $\begin{array}{l}0-5: 80 \% \\
5-10: 17 \% \\
10-15: 4 \% \\
15-20: 3 \%\end{array}$ & $\begin{array}{l}0-5: 88 \% \\
5-10: 10 \% \\
10-15: 1 \% \\
15-20: 0 \%\end{array}$ & 0.621 \\
\hline $\begin{array}{l}\text { The main problem of } \\
\text { Endocrowns is Secondary } \\
\text { Caries. }\end{array}$ & $\begin{array}{l}\text { Strongly disagree: } \mathbf{1 0} \% \\
\text { Disagree: } 87 \% \\
\text { Agree: } 3 \%\end{array}$ & $\begin{array}{l}\text { Strongly disagree: } 10 \% \\
\text { Disagree: } 98 \% \\
\text { Agree: } 2 \%\end{array}$ & 0.972 \\
\hline $\begin{array}{l}\text { Often the Endocrowns Cause } \\
\text { Vertical Fracture for the root. }\end{array}$ & $\begin{array}{l}\text { Strongly disagree: } 8 \% \\
\text { Disagree: } 92 \%\end{array}$ & $\begin{array}{l}\text { Strongly disagree: } 5 \% \\
\text { Disagree: } 95 \%\end{array}$ & 0.415 \\
\hline $\begin{array}{l}\text { Endocrowns have Long Life } \\
\text { Span than all Ceramic } \\
\text { Crowns. }\end{array}$ & $\begin{array}{l}\text { Strongly disagree: } \mathbf{8 \%} \\
\text { Disagree: } \mathbf{8 7} \% \\
\text { Agree: } \mathbf{5} \%\end{array}$ & $\begin{array}{l}\text { Strongly disagree: } 0 \% \\
\text { Disagree: } 98 \% \\
\text { Agree: } 2 \%\end{array}$ & 0.134 \\
\hline $\begin{array}{l}\text { EndoCrowns allow longer life } \\
\text { span for a RCT tooth rather } \\
\text { than All ceramic crowns } \\
\text { because it's more } \\
\text { conservative. }\end{array}$ & $\begin{array}{l}\text { Strongly disagree: } 5 \% \\
\text { Disagree: } 78 \% \\
\text { Agree: } 13 \% \\
\text { Strongly agree: } 4 \%\end{array}$ & $\begin{array}{l}\text { Strongly disagree: } 0 \% \\
\text { Disagree: } 94 \% \\
\text { Agree: } 6 \% \\
\text { Strongly agree: } 0 \%\end{array}$ & 0.199 \\
\hline $\begin{array}{l}\text { Endocrowns cost less than All } \\
\text { Ceramic Crowns. }\end{array}$ & $\begin{array}{l}\text { Strongly disagree: } 2 \% \\
\text { Disagree: } 77 \% \\
\text { Agree: } 12 \% \\
\text { Strongly agree: } 10 \%\end{array}$ & $\begin{array}{l}\text { Strongly disagree: } 0 \% \\
\text { Disagree: } 96 \% \\
\text { Agree: } 4 \% \\
\text { Strongly agree: } 0 \%\end{array}$ & 0.078 \\
\hline $\begin{array}{l}\text { Does the minimal } \\
\text { preparation effect of bonding } \\
\text { and retention? }\end{array}$ & $\begin{array}{l}\text { Strongly disagree: } 20 \% \\
\text { Disagree: } 78 \% \\
\text { Agree: } 2 \%\end{array}$ & $\begin{array}{l}\text { Strongly disagree: } 13 \% \\
\text { Disagree: } 87 \% \\
\text { Agree: } 0 \%\end{array}$ & 0.426 \\
\hline
\end{tabular}

Table 1: Survey questions' comparisons on the basis of gender

\begin{tabular}{l} 
Survey Questions \\
How many patients did \\
you treated by placing \\
EndoCrown in your clinic? \\
\hline The main problem of \\
EndoCrowns is Secondary \\
Caries. \\
\hline Often the Endocrowns \\
Cause Vertical Fracture for \\
the root. \\
\hline Endocrowns have Long \\
Life Span than all Ceramic \\
Crowns. \\
\hline EndoCrowns allow longer \\
life span for a RCT tooth \\
rather than All ceramic \\
crowns because it's more \\
conservative. \\
\hline Endocrowns cost less than \\
All Ceramic Crowns. \\
poes the minimal \\
bonding and retention?
\end{tabular}

\begin{tabular}{|l|}
\hline Dental Intern \\
\hline $0-5: 91 \%$ \\
5-10: $9 \%$ \\
$10-15: 0 \%$ \\
15-20: $0 \%$ \\
\hline Strongly disagree: \\
$0 \%$ \\
Disagree: $98 \%$ \\
Agree: $2 \%$ \\
\hline Strongly disagree: \\
9\% \\
Disagree: $91 \%$ \\
\hline Strongly disagree: \\
0\% \\
Disagree: $97 \%$ \\
Agree: $3 \%$ \\
\hline Strongly disagree: \\
0\% \\
\hline Disagree: $8 \%$ \\
Agree: $92 \%$ \\
Strongly agree: $0 \%$ \\
\hline Strongly disagree: \\
\hline $0 \%$ \\
\hline Disagree: $89 \%$ \\
Agree: $11 \%$ \\
Strongly agree: $0 \%$ \\
\hline Strongly disagree: \\
\hline $11 \%$ \\
\hline Disagree: $89 \%$ \\
Agree: $0 \%$ \\
\hline
\end{tabular}

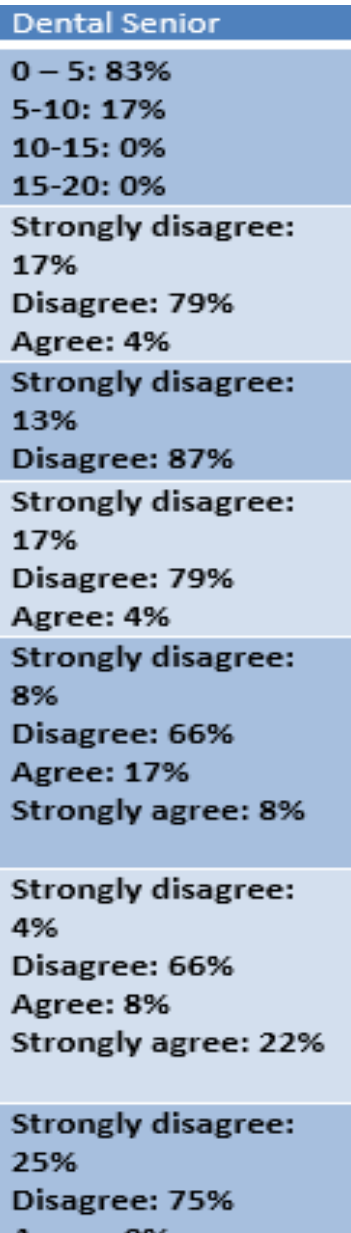

\begin{tabular}{|c|c|}
\hline Prosthodontist & P-value \\
\hline $\begin{array}{l}0-5: 76 \% \\
5-10: 20 \% \\
10-15: 2 \% \\
15-20: 2 \%\end{array}$ & 0.542 \\
\hline $\begin{array}{l}\text { Strongly } \\
\text { disagree: } \mathbf{1 5 \%} \\
\text { Disagree: } \mathbf{8 3} \% \\
\text { Agree: } 2 \%\end{array}$ & 0.180 \\
\hline $\begin{array}{l}\text { Strongly } \\
\text { disagree: } 2 \% \\
\text { Disagree: } 98 \%\end{array}$ & 0.278 \\
\hline $\begin{array}{l}\text { Strongly } \\
\text { disagree: } 2 \% \\
\text { Disagree: } 96 \% \\
\text { Agree: } 2 \%\end{array}$ & 0.044 \\
\hline $\begin{array}{l}\text { Strongly } \\
\text { disagree: } 2 \% \\
\text { Disagree: } 90 \% \\
\text { Agree: } 8 \% \\
\text { Strongly agree: } \\
0 \%\end{array}$ & 0.061 \\
\hline $\begin{array}{l}\text { Strongly } \\
\text { disagree: } 0 \% \\
\text { Disagree: } 90 \% \\
\text { Agree: } 7 \% \\
\text { Strongly agree: } \\
2 \%\end{array}$ & 0.012 \\
\hline $\begin{array}{l}\text { Strongly } \\
\text { disagree: } \mathbf{1 7 \%} \\
\text { Disagree: } \mathbf{8 0 \%} \\
\text { Agree: } 3 \%\end{array}$ & 0.506 \\
\hline
\end{tabular}

Table 2: Survey questions comparison on the basis of academic degree 


\section{Discussion}

The project of the restorative treatment of molars with a large coronal destruction, a clinical challenge, requires careful planning. Therefore the dentist has to decide for the best treatment option to ensure an efficient treatment providing clinical longevity of molars.

The endo crown is convenient for all molars, particularly those with clinically low crowns, calcified root canals, or narrow canals. But it is not recommended if adhesion cannot be assured, if the pulpal chamber is less than $3 \mathrm{~mm}$ deep, or if the cervical margin is less than $2 \mathrm{~mm}$ wide for most of its circumference.

This has been shown to be an advantageous technique as the procedure is easy; it facilitates the steps of impression taking and protects the periodontium. Also, the use of ceramic has the advantages of biocompatibility and biomimicry and its wear coefficient is close to that of the natural tooth. Furthermore, the single interface of a 1-piece restoration makes cohesion look better.

The objective of the preparation is to get a wide and stable surface resisting the compressive stresses that are frequent in molars. The prepared surface is parallel to the occlusal plane to provide stress resistance along the major axis of the tooth. The stress levels in teeth with endo crowns were lower than in teeth with prosthetic crowns.

Due to the development of adhesive cementation systems, the need for macro retentive preparation for crowns has decreased.

In 2018, Dartora et al. have evaluated the biomechanical behavior of endodontically treated teeth restored using different extensions of endo crowns inside the pulp chamber; it has concluded that the greater extension of endo crowns provided better mechanical performance. A $5 \mathrm{~mm}$ extension presented lower intensity and a better stress distribution pattern than a $1 \mathrm{~mm}$ extension which presented a low fracture resistance and a high possibility of rotating the piece when in function.

An in vitro study performed by Taha et al. was done to assess the effect of varying the margin designs on the fracture resistance of endodontically treated teeth restored with polymer-infiltrated ceramic endo crown restorations. The results showed that endo crowns with axial reduction and a shoulder finish line had higher mean fracture resistance values than endo crowns with butt margin design.

It has been also shown that butt joint designs provided a stable surface that resists the compressive stresses because it is prepared parallel to the occlusal plane.

In 2012, Biacchi and Basting compared the fracture strength of 2 types of full ceramic crowns: indirect conventional crowns retained by glass fiber posts and endo crowns. They came to the conclusion that endo crowns were more resistant to compressive forces than the first ones. More recently, finite element analysis highlighted the role of endo crowns in stress distribution.

According to Schultheis et al., endo crown seems to be a more reliable alternative for posterior loadbearing teeth, whereas a bilayer configuration is more susceptible to reduce load fracture failure As stated by Biacchi et al., endo crowns procure adequate function and esthetics and preserve the biomechanical integrity of nonvital posterior teeth. The restoration is reported to be less exposed to the adverse effects of degradation of the hybrid layer.

A research comparing equivalent stresses in molars restored with endo crowns as well as posts and cores during masticatory simulation using finite element analysis revealed that teeth restored by endo crowns are potentially more resistant to failure than those with FRC posts. This study also showed that under physiological loads, ceramic endo crowns ideally cemented in molars should not be damaged or deboned.

\section{Conclusion}

Endo crowns prove that its better than full crown coverage and better fracture resistance than composite restoration. It avoids a large destructive preparation to the tooth in compare of full crown coverage. From the financial aspect Endo crowns almost equal full crown coverage in many of 
Riyadh city clinics.

However, the study shows the importance of choosing the cases that are suitable for endo crowns, importance of the proper preparation and insure good isolation during cementing to get best results.

\section{References}

1. Bindl A, Mörmann WH. . (1999) Clinical evaluation of adhesively placed Cerec endo-crowns after 2 years - preliminary results. J Adhes Dent. .

2. D. Taha, S. Spintzyk, C. Schille et al.(2018). "Fracture resistance and failure modes of polymer infiltrated ceramic endocrown restorations with variations in margin design and occlusal thickness," Journal of Prosthodontic Research.

3. Dietschi D, Duc O, Krejci I, Sadan A. (2008). Biomechanical considerations for the restoration of endodontically treated teeth: a systematic review of the literature, Part II (Evaluation of fatigue behavior, interfaces, and in vivo studies).

4. Fernandes AS, Dessai GS.( 2001). Factors affecting the fracture resistance of postcore reconstructed teeth: a review. Int $J$ Prosthodont.

5. Faria AC, Rodrigues RC, de Almeida Antunes RP, de Mattos MG, Ribeiro RF.( 2011). Endodontically treated teeth: characteristics and considerations to restore them. J Prosthodont Res..

6. G. R. Biacchi and R. T. Basting, (2012). "Comparison of fracture strength of endocrowns and glass fiber post-retained conventional crowns," Operative Dentistry.

7. Johnson JK, Schwartz NL, Blackwell RT. (1976). Evaluation and restoration of endodontically treated posterior teeth. J Endod .

8. Linn J, Messer HH. . (1994). Effect of restorative procedures on the strength of endodontically treated molars. J Endod .
9. Lin CL, Chang YH, Chang CY, Pai CA, Huang SF. Finite element and Weibull analyses to estimate failure risks in the ceramic endocrown and classical crown for endodontically treated maxillary premolar. Eur J Oral Sci. .

10. Magne P, Knezevic A.( 2009). Simulated fatigue resistance of composite resin versus porcelain CAD/CAM overlay restorations on endodontically treated molars.

11. N. R. Dartora, M. B. de Conto Ferreira, I. C. M. Moris et al., (2018)."Effect of intracoronal depth of teeth restored with endocrowns on fracture resistance: in vitro and 3-dimensional finite element analysis," Journal of Endodontia.

12. Oliveira FC, Denehy GE, Boyer DB. (1987). Fracture resistance of endodontically prepared teeth using various restorative materials. J Am Dent Assoc .

13. Pissis P.(1995). Fabrication of a metal-free ceramic restoration utilizing the monobloc technique. Pract Periodontics Aesthet Dent. .

14. S. Schultheis, J. R. Strub, T. A. Gerds, and P. C. Guess,(2013). "Monolithic and bilayer CAD/CAM lithium-disilicate versus metal-ceramic fixed dental prostheses: comparison of fracture loads and failure modes after fatigue," Clinical Oral Investigations.

15. Sedrez-Prto JA, de Oliveira da Rosa WL, da Silva AF, et al: (2016). Endocrown restorations: A systematic review and meta-analysis. J Dent .

16. Zarone F, Sorrentino R, Apicella D, Valentino B, Ferrari M, Aversa R et al. (2006). Evaluation of the biomechanical behavior of maxillary central incisors restored by means of endocrowns compared to a natural tooth: a 3D static linear finite elements analysis. J Endod .

17. Zahran M, El-Mowafy O, Tam L, Watson 
PA, Finer Y.( 2008) . Fracture strength and fatigue resistance of all-ceramic molar crowns manufactured with $\mathrm{CAD} / \mathrm{CAM}$ technology. J Prosthodont. .

18. Zarone F, Sorrentino R, Apicella D, Valentino B, Ferrari M, Aversa R et al. (2006 ). Evaluation of the biomechanical behavior of maxillary central incisors restored by means of endocrowns compared to a natural tooth: a 3D static linear finite elements analysis. Dent Mater. 